\title{
How to assess orodispersible film quality? A review of applied methods and their modifications
}

KATARZYNA WASILEWSKA

KATARZYNA WINNICKA*

Department of Pharmaceutical

Technology, Medical University of

Bialystok, Bialystok 15-089, Poland
Accepted November 16, 2018

Published online December, 2018

\begin{abstract}
In recent years, there has been a tendency toward creating innovative, easy to use and patient-friendly drug delivery systems suitable for every consumer profile, which would ensure safety, stability and acceptability of a drug. One of the relatively novel and promising approaches is the manufacture of orodispersible films (ODFs), which is an upcoming area of interest in drug delivery. They are defined as polymer thin films that disintegrate in the oral cavity within seconds, without drinking water or chewing, and eliminate the risk of choking. Gaining special usefulness in therapies of children and the elderly, ODFs seem to fill the gap in the range of preparations available for these groups of patients. As no detailed monography of ODFs including testing methods and uniform requirements has been presented in any of the pharmacopoeias to date, the aim of this article is to give an overview of the applied testing methods, their modifications and innovative approaches related to ODF quality assessment.
\end{abstract}

Keywords: orodispersible film, quality assessment, ODF testing methods, mechanical properties, disintegration time

\section{INTRODUCTION}

Oral application is the most acceptable, noninvasive and widely used route of drug administration (1). Various dosage forms for oral drug delivery: syrups, suspensions, drops, tablets, capsules or chewing gums are available (2). However, each of them raises some problems related to their administration and dosing (3). Moreover, several groups of patients have considerable swallowing difficulties, dysphagia or fear of choking, which hamper their therapy as well as complicate patient compliance and adherence (4-9). In order to eliminate difficulties exhibited by traditional solid oral dosage forms and meet the expectations of today's patients, more and more formulations appear as orodispersible drug delivery systems, which include orodispersible tablets (ODTs) and orodispersible films (ODFs) (10, 11). Use of orodispersible formulations avoids the risk of choking, which may occur in the case of conventional tablets or capsules (5). It is also suitable for patients

*Correspondence; e-mail: katarzyna.winnicka@umb.edu.pl 
K. Wasilewska and K. Winnicka: How to assess orodispersible film quality? A review of applied methods and their modifications, Acta Pharm. 69 (2019) 155-176.

Table I. Examples of ODFs available as OTC or Rx products in chronological order

\begin{tabular}{|c|c|c|}
\hline $\begin{array}{l}\text { Registration } \\
\text { year }\end{array}$ & Product & Reference \\
\hline 2001 & Listerine PocketPaks ${ }^{\circledR}$ Oral Care Strips (OTC) & $17,24,25,27$ \\
\hline 2004 & $\begin{array}{l}\text { Chloraseptic }{ }^{\circledR} \text { Sore Throat Relief Strips (OTC), Triaminic Thin Strips }{ }^{\circledR} \\
\text { (OTC), Theraflu }{ }^{\circledR} \text { Thin Strips (OTC) }\end{array}$ & 24,25 \\
\hline 2005 & Sudafed ${ }^{\circledast}$ Pe Quick Dissolve Strips (OTC) & 25 \\
\hline 2006 & Gas-X Thin Strips ${ }^{\circledR}$, Benadry ${ }^{\circledR}$ Allergy Quick Dissolve Strips (OTC) & 25,28 \\
\hline 2008 & Pedia-Lax ${ }^{\mathrm{TM}}$ Quick Dissolve Strips (OTC) & 25,28 \\
\hline 2010 & Ondansetron RapidFilm ${ }^{\circledR}(\mathrm{Rx})$, Risperidon $\mathrm{HEXAL}^{\circledR} \mathrm{SF}(\mathrm{Rx})$ & 25,29 \\
\hline 2012 & Niquitin ${ }^{\circledR}$ Strips (OTC), Zuplenz (Rx) & 25 \\
\hline 2013 & ZolmitriptanRapidFilm ${ }^{\circledR}(\mathrm{Rx})$ & 25 \\
\hline 2014 & Sildenafil Sandoz Orodispersible Film ${ }^{\circledR}(\mathrm{Rx})$ & 30 \\
\hline 2016 & IvyFilm $^{\circledR}$, IvyFilm Kiddies ${ }^{\circledR}(\mathrm{OTC})$ & 31 \\
\hline 2018 & Clobazam OSF ${ }^{\circledR}(\mathrm{Rx})$ & 32 \\
\hline
\end{tabular}

who are not willing to cooperate or face the difficulties associated with complete dosage intake, such as patients with depression, schizophrenia, dementia and other neurodegenerative diseases (11-13). In particular, ODFs are at the cutting edge of drug technology as they offer a good alternative for rapid drug delivery (14). Their origins date back to the 1970s but only after being marketed by Pfizer in 2001 as refreshing breath strips Listerine PocketPaks ${ }^{\circledR}$, they started gaining popularity and their potential as a drug delivery system was discerned (Table I) (15-17). According to the European Pharmacopoeia (Ph. Eur.), ODFs are defined as "single or multilayered sheets of suitable materials, to be placed in the mouth where they disperse rapidly" (18). European Medicines Agency (EMA) recommended the nomenclature "orodispersible films" (19) and Food and Drug Administration (FDA) named them "oral soluble films" (20).

A number of other terms can be found in literature: oral strips, thin strips, fast dissolving films, mouth dissolving films, oral wafers or fast dissolving films (21-23). ODFs appear as over the counter (OTC) and prescription ( $\mathrm{Rx}$ ) preparations from different therapeutic classes (Table II) (24). The first Rx films approved in the European Union in 2010 (Table I) were Ondansetron RapidFilm ${ }^{\circledR}$ and Risperidon $\operatorname{HEXAL}^{\circledR}$ SF Schmelzfilm $(24,25)$. Interestingly, ODFs are a suitable dosage form not only for humans but they are also an alternative for animal oral drug administration, which is usually troublesome (Table II) (26).

ODFs are described as postage stamp-sized polymer films, with a thickness ranging from 12 to $100 \mu \mathrm{m}$ and surface from 2 to $8 \mathrm{~cm}^{2}$ (commonly given dimensions in literature are $\left.3 \times 2 \mathrm{~cm}^{2}, 2 \times 2 \mathrm{~cm}^{2}\right)(39-41)$. ODFs contain one or more therapeutic substances that constitute up to $30 \%$ of film mass. Essential excipients are polymers, which seem to be the backbone of film formulations (40-50 \% of film mass), and plasticizers usually adding up to $20 \%$ of dry polymer weight. Other components include: taste masking agents, sweeteners, surfactants or saliva stimulating agents $(14,24,39-43)$. ODFs are manufactured by the following methods: solvent casting, hot melt extrusion, semisolid casting method, rolling 
K. Wasilewska and K. Winnicka: How to assess orodispersible film quality? A review of applied methods and their modifications, Acta Pharm. 69 (2019) 155-176.

Table II. Composition of selected ODF preparations as OTC or Rx products

\begin{tabular}{|c|c|c|c|c|}
\hline Trade name & API & Polymer & Plasticizer & Reference \\
\hline \multicolumn{5}{|l|}{ OTC products } \\
\hline $\begin{array}{l}\text { Listerine PocketPaks }{ }^{\circledR} \text { Oral Care } \\
\text { Strips (Johnson\&Johnson) }\end{array}$ & Menthol & Pullulan & $\begin{array}{l}\text { Glyceryl Oleate } \\
\text { Macrogol }\end{array}$ & $17,24,33$ \\
\hline $\begin{array}{l}\text { Sudafed }{ }^{\circledR} \text { PE } \\
\text { (Johnson\&Johnson) }\end{array}$ & Phenylephrine & $\begin{array}{l}\text { Maltodextrin } \\
\text { Pullulan } \\
\text { Carragen }\end{array}$ & Glycerin & $24,34,35$ \\
\hline $\begin{array}{l}\text { Theraflu }{ }^{\circledR} \text { Day Time Thin Strips } \\
\text { (Novartis Consumer Healthcare) }\end{array}$ & $\begin{array}{l}\text { Dextromethorphan } \\
\text { Diphenhydramine } \\
\text { Phenylephrine }\end{array}$ & $\begin{array}{l}\text { Hypromellose } \\
\text { (HPMC) } \\
\text { Maltodextrin }\end{array}$ & $\begin{array}{l}\text { Propylene Glycol } \\
\text { Macrogol }\end{array}$ & 24,27 \\
\hline $\begin{array}{l}\text { Gas-X Thin Strips }{ }^{\circledR} \\
\text { (Novartis Consumer Healthcare) }\end{array}$ & Simethicone & $\begin{array}{l}\text { Maltodextrin } \\
\text { HPMC }\end{array}$ & $\begin{array}{l}\text { Polyethylene } \\
\text { glycol } \\
\text { Sorbitol }\end{array}$ & 34,35 \\
\hline $\begin{array}{l}\text { Chloraseptic }{ }^{\circledR} \text { Sore Throat Relief } \\
\text { Strips (InnoZen) }\end{array}$ & Benzocaine & Corn starch & $\begin{array}{l}\text { Erythritol } \\
\text { Macrogol }\end{array}$ & $23,27,35$ \\
\hline $\begin{array}{l}\text { Supress Cough Strips }{ }^{\circledR} \\
\text { (InnoZen) }\end{array}$ & Menthol & $\begin{array}{l}\text { Carragen } \\
\text { Pectin } \\
\text { Sodium alginate }\end{array}$ & Glycerin & 23,27 \\
\hline $\begin{array}{l}\text { Pedia-Lax }{ }^{\mathrm{TM}} \text { Quick Dissolve Strip } \\
\text { (C. B. Fleet) }\end{array}$ & Sennosides & HPMC & Glycerin & 28,35 \\
\hline $\begin{array}{l}\text { SpotScent Oral Care } \\
\text { Strips }{ }^{\circledR} \text { (breathfreshener for dogs) } \\
\text { (Spotscent) }\end{array}$ & Parsleyseed oil & $\begin{array}{l}\text { Modified } \\
\text { cellulose }\end{array}$ & Glycerin & 26 \\
\hline $\begin{array}{l}\text { Orajel }^{\mathrm{TM}} \text { Kids Sore Throat Relief Strips } \\
\text { (Church \& Dwight Co.) }\end{array}$ & Benzocaine & Pectin & Glycerin & 24 \\
\hline $\begin{array}{l}\text { Day Time Triaminic Thin Strips }{ }^{\circledR} \\
\text { Cough \& Cold } \\
\text { (NovartisConsumer Healthcare) }\end{array}$ & $\begin{array}{l}\text { Phenylephrine } \\
\text { Dextromethorphan }\end{array}$ & HPMC & $\begin{array}{l}\text { Polyethylene } \\
\text { Glycol }\end{array}$ & 24,27 \\
\hline $\begin{array}{l}\text { IvyFilm }^{\circledR} \text {, IvyFilm Kiddies }{ }^{\circledR} \\
\text { (Lamar-Forrester Pharma) }\end{array}$ & Hedera helix extract & Pullulan & Glycerin & 31 \\
\hline $\begin{array}{l}\text { Benadryl }{ }^{\circledR} \text { Allergy quick dissolve } \\
\text { strips (McNeill-PPC) }\end{array}$ & Diphenhydramine & $\begin{array}{l}\text { Carragen } \\
\text { Pullulan }\end{array}$ & Glycerin & 24 \\
\hline \multicolumn{5}{|l|}{ Rx products } \\
\hline $\begin{array}{l}\text { Sildenafil Sandoz Orodispersible } \\
\text { film }^{\circledR} \text { (Sandoz) }\end{array}$ & Sildenafil & HHPMC & Glycerin & 30 \\
\hline $\begin{array}{l}\text { Sildenafil IBSA } \\
\text { Orodispersible film } \\
\text { (IBSA Farmaceutici Italia Srl) }\end{array}$ & Sildenafil & DMaltodextrin & $\begin{array}{l}\text { Glycerin } \\
\text { Polysorbate } \\
\text { Propylene glycol } \\
\text { Monocaprylate }\end{array}$ & 36,37 \\
\hline $\begin{array}{l}\text { Zuplenz }^{\circledR} \\
\text { (VestiqPharmaceuticals) }\end{array}$ & Ondansetron & HНPMC & $\begin{array}{l}\text { Polyethylene } \\
\text { Oxide } \\
\text { Colloidal } \\
\text { Silicon Dioxide }\end{array}$ & 24 \\
\hline $\begin{array}{l}\text { Risperidon HEXAL }{ }^{\circledR} \\
\text { SF Schmelzfilm } \\
\text { (Hexal AG) }\end{array}$ & Risperidone & $\begin{array}{l}\text { HHPMC } \\
\text { Maltodextrin }\end{array}$ & Glycerin & 24,38 \\
\hline
\end{tabular}


method or electrospinning $(8,44)$. An ODF is designed to be placed on the tongue, where it is wetted with saliva in a few seconds, then the film-forming polymer is rapidly dissolved (up to $30 \mathrm{~s}$ ) and the active pharmaceutical ingredient (API) begins to dissolve and release $(45,46)$. Most of the drug is swallowed with the saliva and then absorbed from the gastrointestinal tract; however, absorption of an API fraction through the oral mucosa may occur. Ideal ODFs should exhibit adequate elasticity, flexibility, softness, mechanical properties to facilitate their production, packaging and application, short disintegration time and pleasant taste. All these parameters have to be evaluated (15).

In recent years, there has been an increasing amount of newly developed poorly water-soluble APIs in pharmaceutical technology; new technologies were therefore introduced to improve their bioavailability (47). Administration of such drugs, especially at high doses, requires technological modifications enabling enhanced dissolution, which might be achieved by creating nanocrystals or nanoparticles (48). Reduction of the particle size results in an increase of their surface area, and thus provides increased saturation, solubility, fast dissolution and consequently improved bioavailability of APIs (49). Nanoparticles can be either in amorphous or crystalline state and amorphous material has a higher apparent solubility than crystals (50). Incorporation of nanocrystals or nanoparticles is now applied in the formulation of ODFs $(51,52)$ and might affect their mechanical properties. Young's modulus measurements suggest that nanocrystals or nanoparticles change film stiffness significantly (53).

\section{EXCIPIENTS USED IN ODF PREPARATION}

Film-forming polymers are key components in the manufacturing of ODFs. To strike a balance between mechanical properties and disintegration time of ODFs, proper selection of polymer type and concentration is an important issue $(54,55)$. Polymer properties are principally affected by their molecular mass $(23,56)$. To compare the effect of molecular weight on film properties, ODFs were prepared with low and high molecular mass maltodextrin. Results of the experiment revealed that films made of maltodextrin with high molecular mass were stiffer and less sticky than those obtained with lower molecular mass maltodextrin. Moreover, their tensile strength and elastic modulus were higher, whereas elongation at break was lower. Viscosity of the mixture provided by the polymer prevents API sedimentation, provides homogeneous dispersion of all ingredients and facilitates the manufacturing process. Ideal viscosity should be high enough to prevent sedimentation of particles, but at the same time not too high so as to avoid problems during the manufacture $(57,58)$. The most commonly used polymers are cellulose derivatives, polyvinyl alcohol and pullulan (Table III) (23, 59-62).

There are examples of films based on mixtures of different polymers such as: hypromellose and methacrylic acid copolymers (22); polyvinyl alcohol or polyvinylpyrrolidone and croscarmellose sodium (66-68); high molecular mass povidones and synthetic copolymers of macrogol-polyvinyl alcohol (Kollidon, Kollicoat) (69); carboxymethylcellulose, hypromellose and sodium alginate (70). Plasticizers are another major group of excipients used in ODF manufacturing (Table III). There are many publications on the influence of plasticizers on film characteristics, and the choice of a proper one or their mixture is a crucial issue $(14,23,29,38,55,71)$. As an example, macrogol with citric acid esters added should not be used to plasticize maltodextrin ODFs due to the lack of miscibility. Also, 
K. Wasilewska and K. Winnicka: How to assess orodispersible film quality? A review of applied methods and their modifications, Acta Pharm. 69 (2019) 155-176.

Table III. Excipients used in ODF formulation

\begin{tabular}{|c|c|c|c|}
\hline Excipient & Excipient role & Excipient example & Reference \\
\hline Polymers & $\begin{array}{l}\text { - Enable rapid disintegration upon } \\
\text { contact with saliva } \\
\text { - Guarantee adequate mechanical } \\
\text { properties and integrity } \\
\text { - Provide the necessary elasticity } \\
\text { and shape of the film }\end{array}$ & $\begin{array}{l}\text { Natural polymers } \\
\text { starch, sodium alginate, pullulan, } \\
\text { pectin, gelatin, maltodextrin, } \\
\text { levan, zein, collagen, amylose, } \\
\text { cellulose derivatives, chitosan } \\
\text { Synthetic polymers } \\
\text { polyvinyl alcohol (PVA), polyvinyl } \\
\text { acetate, methacrylic acid copoly- } \\
\text { mers }\end{array}$ & $\begin{array}{l}24,38,54 \\
63-65\end{array}$ \\
\hline Plasticizers & $\begin{array}{l}\text { - Improve tensile strength and } \\
\text { percent elongation } \\
\text { - Prevent crushing, reduce glass } \\
\text { transition temperature of the } \\
\text { polymer } \\
\text { - Reduce brittleness } \\
\text { - Improve plasticity of the polymer } \\
\text { which affects film flexibility } \\
\text { - Improve API solubility and } \\
\text { absorption } \\
\text { - Affect mechanical properties } \\
\text { - Some plasticizers improve taste } \\
\text { masking efficiency (e.g., sorbitol, } \\
\text { mannitol, glycerol) }\end{array}$ & $\begin{array}{l}\text { Sorbitol, mannitol, glycerol, diethyl } \\
\text { phthalate, triethyl citrate, tributyl } \\
\text { citrate, sorbitol, macrogol, } \\
\text { propylene glycol, citric acid esters }\end{array}$ & \\
\hline Surfactants & $\begin{array}{l}\text { - Solubilizing, dispersing, wetting } \\
\text { agents } \\
\text { - Enable films to disintegrate } \\
\text { within seconds during contact } \\
\text { with saliva }\end{array}$ & $\begin{array}{l}\text { Poloxamer } 407 \text {, sodium lauryl } \\
\text { sulfate, polysorbate }\end{array}$ & 24,38 \\
\hline $\begin{array}{l}\text { Sweetening } \\
\text { and taste } \\
\text { masking agents }\end{array}$ & $\begin{array}{l}\text { - Mask bitter or nauseating taste, } \\
\text { especially important in case of } \\
\text { pediatric population }\end{array}$ & $\begin{array}{l}\text { Flavored essences, aspartame, } \\
\text { sucralose, cyclamate, glucose, } \\
\text { fructose, oleoresins, ribose, } \\
\text { sucrose, maltose, thaumatin I and } \\
\text { II, sorbitol, mannitol }\end{array}$ & 24,38 \\
\hline $\begin{array}{l}\text { Saliva } \\
\text { stimulators }\end{array}$ & $\begin{array}{l}\text { - Stimulate production of saliva in } \\
\text { oral cavity }\end{array}$ & $\begin{array}{l}\text { Malic acid, tartaric acid, ascorbic } \\
\text { acid, lactic acid }\end{array}$ & 24,38 \\
\hline
\end{tabular}

*All excipients used in ODF manufacture have to be approved for use in oral pharmaceutical dosage forms.

increasing the glycerol or propylene glycol content in maltodextrin ODFs caused elastic modulus reduction and elongation at break boost. Their concentration in amounts higher than $18 \%(\mathrm{~m} / \mathrm{m})$ caused ODF stickiness (57). In vivo organoleptic tests have shown that films with polyethylene glycol or a polyethylene glycol/glycerol mixture were characterized by unpleasant taste (72) and films plasticized only with glycerol had a more pleasant taste than those with propylene glycol (57). As ODFs are intended to dissolve or disintegrate in 
the mouth, the taste of the formulation is a great challenge in this dosage form development. Unpleasant taste of APIs should be masked well enough to become acceptable both to children and adults, but the risk of overdosing a "candy-like" formulation (especially by young patients) should be kept in mind (73). However, it is known that "a spoon full of sugar helps the medicine go down", as Mary Poppins, a character from a children's book, used to say, which certainly applies to the designing of pediatric formulations (74).

\section{TESTING METHODS}

ODFs represent a relatively new drug dosage form. ODFs first became a part of the $7^{\text {th }}$ $\mathrm{Ph}$. Eur. edition in 2012, which included their general monograph. Only the release test is mentioned in Ph. Eur. to demonstrate the appropriate release of API and according to pharmacopoeial requirements ODFs "should possess suitable mechanical strength to resist handling without being damaged" (18).

Questions arising here include what the suitable mechanical strength means and exactly in what way a dissolution test should be carried out. As there are no standards of quality control methods in the pharmacopoeia, the logical assumption is that there is a need for unification of quality studies. Absence of standardized methods and equipment causes problems of how to develop a formulation characterized by optimal parameters (33). There is currently a tendency of using testing methods recommended for solid oral dosage forms (tablets and capsules), which in fact are not adequate for assessment of ODFs, since they do not relate to specific characteristics of ODFs and conditions to which they are subjected in the oral cavity (75). Also, the literature reveals a large number of individually modified methods and industrial directives (e.g., for plastics and paints: DIN EN ISO 527-3, 2012; ASTM D 882-02, 2012) that may be utilized in quality evaluation of ODFs $(76,77)$. Therefore, elaboration of gold standard methods for assessing their properties and testing approaches is of the utmost importance $(62,78)$.

\section{Disintegration time and release tests}

In the pharmaceutical technology, both from the drug development and quality control perspective, disintegration time and drug release tests are essential tools to estimate dosage form properties $(79,80)$. In the case of ODFs, disintegration and release procedures are difficult to distinguish due to the short time in which they occur (81). According to the International Pharmaceutical Federation/American Association of Pharmaceutical Scientists (FIP/ AAPS) guidelines for ODT (which may be applied to ODFs), a disintegration test may be used instead of a dissolution test if it is shown to be a good discriminating method (75). If API appears as molecular dissolution in the ODF, then the released API rate depends only on the disintegration time of the film. However, if API is dispersed in the film, both disintegration time and dissolution tests are recommended (82). Properly conducted disintegration time examination is crucial for evaluation of orodispersible dosage forms. Reference to ODT disintegration time, which is up to 3 min according to the Ph. Eur. (83) and $30 \mathrm{~s}$ or less according to the FDA and USP guidelines $(20,84)$, is recommended. The test is usually performed using pharmacopoeial apparatus for studying the disintegration time of conventional solid dosage forms (tablets and capsules) $(85,86)$. As the apparatus requires large volumes of solution to perform the test, it does not mimic the oral cavity conditions. More- 
over, the mechanical force of the tongue is not reflected either $(24,87)$. Therefore, some modifications, like using a sample holder to keep ODF vertically in the disintegration tester with attached weights to facilitate observation of the disintegration endpoint, are proposed (38, 88). However, using disks or weights may disesteem the disintegration time because of additional forces exerted on the ODF while caring out the test (89). As the volume of saliva in the oral cavity is less than $2 \mathrm{~mL}(90)$, tests under conditions similar to those prevailing in the oral cavity conducted in a small volume of medium, usually $2-7 \mathrm{~mL}$, are recommended (72, $91,92)$. ODF might be placed on the liquid surface in a Petri dish and its disintegration time is measured using a stopwatch (the dish may be shaken constantly in order to imitate the movement of the tongue in the mouth) $(73,93)$. This method allows for ease of application and simple test setup. Nevertheless, the endpoint detection creates some difficulties, especially for transparent ODFs and it is very difficult to implement process automatization. Further, neither the adhesion of the film to the oral mucosa nor the influence of the force of the tongue are considered during the test (94). Another approach is the fixing of an ODF in slide frames and placing it horizontally over a Petri dish; a small amount of medium (usually about $200 \mu \mathrm{L}$ ) is then piped onto the ODF surface. The time until the fluid penetrates through the film making a hole is observed and measured with a stopwatch $(92,95)$. This method seems to be appropriate for observing the disintegration time of thin films. For thicker films, a standard volume of medium $(200 \mu \mathrm{L})$ might be too small to disintegrate a thick film layer, which might prolong disintegration time. Obtained results do not correlate with the data of in vivo disintegration, since during the test the films are wetted only from one side, which is not comparable with physiological conditions $(9,94)$. In the method utilizing a wire mesh, the ODF is placed on a stainless steel wire metal mesh where its bottom is wetted by contact with distilled water. The time taken to pass through the mesh is considered as disintegration time $(55,59)$. To improve assessment of the ODF disintegration endpoint, a disintegration test unit (DTU) was developed (Fig. 1). DTU is a modification of the pharmacopoeial test and is used as an accessory to the pharmacopoeial apparatus for disin-

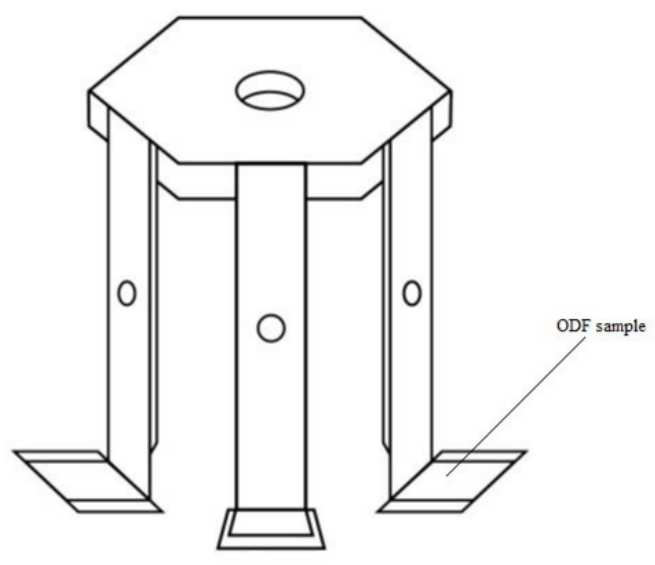

Fig. 1. Schematic illustration of the disintegration time unit for determination of disintegration time endpoint (modified from reference 96). 
tegration time evaluation. It is designed for testing 6 samples simultaneously. DTU is placed in a basket-rack assembly from the top and allows to follow ODF in the vertical plane in the bath (it holds the ODF in horizontal position, allowing a top view of the ODF during testing). DTU moves together with the device for raising and lowering the basket in a $1000-\mathrm{mL}$ beaker and enables easier ODF observation and more precise definition of the endpoint (96).

Another approach is the use of a texture analyzer equipped with a special disintegration rig (used for ODTs), which mimics in vivo conditions in the human mouth. In this test, a flat-ended cylindrical probe penetrates into the ODF immersed in the medium. As the ODF disintegrates, the instrument is set to maintain a small force for a defined period of time. Plots of the distance traveled by the probe, generated with the instrument's software, provide a disintegration profile of the ODF as a function of time. These plots are used to calculate the start and the endpoint of ODF disintegration (97). Another method utilizing a texture analyzer is fixation of ODF to a special platform and setting the probe to mimic the oral cavity forces. At the moment when the film is touched by the probe, $1 \mathrm{~mL}$ of artificial saliva is administered to the film (98). Disintegration behavior can be also analyzed with a newly developed SFaB ("Slide Frame and Ball") device, which is an adjustment to the slide frame method. The main advantages of the device are the indication of the clear endpoint (the ball falls on the bottom of the vessel after complete disintegration) and the consideration of the mechanical stressing component representing the tongue force as well as physiological properties in the mouth $(0.9 \mathrm{~mL}$ of distilled water is utilized). The measurement starts when the fluid drop is dropped on top of the film. Afterwards, the ball $(4 \mathrm{~g})$ is placed in the middle of the film. The test ends when the ball falls through the film. To overcome the difficulties connected with unintended rolling of the ball on the film surface during the disintegrating process, an insert to the SFaB keeping the ball constantly in the centric position was implemented $(53,94)$. Another novel and robust test method enabling clear endpoint detection is the PharmaTest ${ }^{\circledR}$ film disintegration tester PT-ODF (Basket Add-On to Test Orodispersible Films). This is a simple device with a sample holder facilitating assessment of disintegration time. Six ODFs are simultaneously held by clamps in transparent glass tubes. Small weights $(3 \mathrm{~g})$ are fixed to the lower periphery of each film (simulating mechanical force of the tongue) and fall down once the film has disintegrated. The weights clipped on the bottom of the films are considered to simulate the force provided by the tongue. PT-ODF connected to the disintegration basket moves up and down in the medium ( $900 \mathrm{~mL}$ of distilled water, at $37 \pm 0.5^{\circ} \mathrm{C}$ ) in the test vessel. After disintegrating, the weights hit the split metal sieve of the basket and close an electrical circuit. The endpoint is detected automatically and the instrument logs the disintegration time. However, the medium volume used in the test is much larger than in the oral cavity $(94,99)$. In addition, the contact angle (measured by a goniometer) is a parameter indicating the susceptibility of ODF to wetting in contact with the liquid. Angle values below $90^{\circ}$ mean that the film moistens easily, which is indirectly related to disintegration time $(15,44,48)$. However, as none of the methods mimic the physiological conditions adequately, the most reliable disintegration time test is the in vivo measurement performed on volunteers - ODF is placed directly on the tongue and the time required for complete disintegration is recorded (100).

The choice of medium is a very important parameter in ODF assessment, for it influences the disintegration and dissolution process (83). Human saliva is a natural biological fluid, characteristics of which are affected by personal differences, concomitant diseases, time of the day and diet $(101,102)$. As no saliva substitute is defined in the Ph. Eur., it is hard to decide which medium mimics this fluid best (103). Artificial salivas - stimulated 
K. Wasilewska and K. Winnicka: How to assess orodispersible film quality? A review of applied methods and their modifications, Acta Pharm. 69 (2019) 155-176.

Table IV. Different compositions of SSFS

\begin{tabular}{|c|c|c|}
\hline & Media proposed in the literature: Composition and concentration $\left(\mathrm{g} \mathrm{L}^{-1}\right)$ & Reference \\
\hline $\mathrm{SSF}_{1}$ & $\begin{array}{l}\mathrm{KCl}(0.72), \mathrm{CaCl}_{2} \times 2 \mathrm{H}_{2} \mathrm{O}(0.22), \mathrm{NaCl}(0.6), \mathrm{KH}_{2} \mathrm{PO}_{4}(0.68), \mathrm{Na}_{2} \mathrm{HPO}_{4} \\
(0.866), \mathrm{KHCO}_{3}(1.5), \mathrm{KSCN}(0.06) \text {, citric acid (0.03) }\end{array}$ & $107,108,109$ \\
\hline $\mathrm{SSF}_{2}$ & $\begin{array}{l}\mathrm{CaCl}_{2} \times 2 \mathrm{H}_{2} \mathrm{O}(0.228), \mathrm{NaCl}(0.017), \mathrm{Na}_{2} \mathrm{HPO}_{4}(0.204), \mathrm{MgCl}_{2} \times 6 \mathrm{H}_{2} \mathrm{O}(0.061), \\
\mathrm{K}_{2} \mathrm{CO}_{3}(0.603), \mathrm{NaH}_{2} \mathrm{PO}_{4} \times \mathrm{H}_{2} \mathrm{O}(0.273), \text { submaxillary mucin }(1.0), \\
\text { alpha-amylase (2.0) }\end{array}$ & 107,108 \\
\hline $\mathrm{SSF}_{3}$ & $\begin{array}{l}\mathrm{KCl}(0.149), \mathrm{NaCl}(0.017), \mathrm{NaHCO}_{3}(2.1) \text {, alpha-amylase (2.0), gastric } \\
\text { mucin (1.0) }\end{array}$ & 107,108 \\
\hline $\mathrm{SSF}_{4}$ & $\mathrm{NaCl}(8.0), \mathrm{KH}_{2} \mathrm{PO}_{4}(0.19), \mathrm{Na}_{2} \mathrm{HPO}_{4}(2.38)$ & 109,110 \\
\hline $\mathrm{SSF}_{5}$ & $\begin{array}{l}\text { Albumin (0.01), methylcellulose }(0.025), \mathrm{KCl}(0.0062), \mathrm{K}_{2} \mathrm{HPO}_{4}(0.0034) \text {, } \\
\mathrm{NaF}(0.001), \mathrm{MgCl}_{2}(0.0005) \text {, dextrose }(0.469) \text {, methylparaben }(0.02)\end{array}$ & 109,110 \\
\hline $\mathrm{SSF}_{6}$ & $\begin{array}{l}\mathrm{NaCl}(1.256), \mathrm{KCl}(9.639), \mathrm{KSCN}(1.892), \mathrm{KH}_{2} \mathrm{PO}_{4}(6.545), \text { urea (2.0), } \\
\mathrm{Na}_{2} \mathrm{SO}_{4}(7.632), \mathrm{NH}_{4} \mathrm{Cl}(0.178), \mathrm{CaCl}_{2} \times 2 \mathrm{H}_{2} \mathrm{O}(2.278), \mathrm{NaHCO}_{3}(6.308)\end{array}$ & 111,112 \\
\hline \multicolumn{3}{|c|}{ Commercially available media } \\
\hline $\begin{array}{l}\mathrm{SSF}_{7} \\
(\mathrm{AFNOR})\end{array}$ & $\mathrm{NaCl}(0.7), \mathrm{KCl}(1.2), \mathrm{Na}_{2} \mathrm{HPO}_{4}(0.26), \mathrm{NaHCO}_{3}(1.5), \mathrm{KSCN}(0.33)$, urea (1.3) & 113,114 \\
\hline $\begin{array}{l}\mathrm{SSF}_{8} \\
\text { (Fusayama } \\
\text { Mayers) }\end{array}$ & $\mathrm{NaCl}(0.4), \mathrm{KCl}(0.9), \mathrm{CaCl}_{2} \times \mathrm{H}_{2} \mathrm{O}(0.795), \mathrm{NaH}_{2} \mathrm{PO}_{4} \times 2 \mathrm{H}_{2} \mathrm{O}(0.69)$, urea (1.0) & $108,113,114$ \\
\hline
\end{tabular}

Phosphate buffers pH 6.8

\begin{tabular}{llc}
\hline $\mathrm{SSF}_{9}$ & $\mathrm{Na}_{2} \mathrm{HPO}_{4}(71.5), \mathrm{C}_{6} \mathrm{H}_{8} \mathrm{O}_{7}(21.0)$ & $109,112,115$ \\
\hline $\mathrm{SSF}_{10}$ & $\mathrm{KH}_{2} \mathrm{PO}_{4}(50.0), \mathrm{NaOH}(0.2 \mathrm{M})$ & 116 \\
\hline
\end{tabular}

salivary fluids (SSF) - occur as solutions or suspensions containing organic and inorganic compounds. They differ in elemental composition, ionic strength, $\mathrm{pH}$, conductivity or enzyme content (104). In the literature, there are many examples of SSF created by scientists for their laboratory needs, as well as ready-made products (Table IV). However, pharmacopoeial phosphate buffers $\mathrm{pH} 6.8$ are still the most often used media $(105,106)$.

Drug release from ODFs is usually carried out according to the pharmacopoeial requirements for solid oral dosage forms using a basket or paddle apparatus in medium (phosphate buffers pH 6.8 or SSFs) heated to $37^{\circ} \mathrm{C}$ (117-119). However, pharmacopoeial apparatus have some disadvantages (120). Basket apparatus problems may arise with the adhesion and mesh clogging by the film, while paddle apparatus presents phenomena of ODF flotation in dissolution media or local adhesion to the bottom of the vessel, which makes it difficult to achieve data reproducibility $(27,57,121)$. In order to avoid floating and to mimic the in vivo adhesion, sinkers and double-slide tapes are used (each film is fixed to a rectangular glass slab and placed at the bottom of the dissolution vessel) (89). As a result of rapid disintegration, complete release of API takes place very quickly and samples of the analyzed fluid are taken in a short time. FIP/AAPS guidelines for the in vitro release test of novel/special dosage forms suggest using a basket apparatus with higher sampling 
frequency at earlier time points. Determination of the released dose at a time point is also suggested (75). Other approaches involve the use of the Franz diffusion cell $(122,123)$, a syringe with $10 \mathrm{~mL}$ of medium (124) or the microfluidic device (covered by the patent). The microfluidic device mimics physiological conditions of the mouth by the laminar tangential solvent flow with a rate of $1 \mathrm{~mL} \mathrm{~min}^{-1}$ and low hold-up volume $\left(1 \mathrm{~cm}^{3}\right)$. ODF is placed on the bottom surface of a dissolution cell, where it is exposed to tangential solvent flow. Samples are collected at the exit of the cell at different time intervals, filtered and analyzed using an appropriate technique (125). Use of a device based on flow-through cell with a limited amount of dissolution fluid and collecting samples at short time intervals lead to more realistic dissolution profiles (126). Two methods based on paddle apparatus with different dissolution setups utilizing a UV-fiber optical probe as data point detector were described by Krampe et al. (9). Release test might be also performed in a pharmacopoeial dissolution apparatus V (paddle over disk) $(127,128)$.

\section{EVALUATION OF MECHANICAL PROPERTIES}

Mechanical properties play a crucial role in physical integrity of ODFs (53, 61, 81, 129 , 130). They provide information about the resistance to stretching or pulling, which is important during removal, cutting, packaging, transport and patient handling (11). ODFs are tested for the following factors: tensile strength, tear resistance, percentage of elongation, Young modulus, folding endurance (29). As no standard methods for determining their mechanical strength are provided, a wide range of tools and methods are applied $(18,19,84)$.

\section{Tensile properties}

Tensile strength is defined as the maximum stress needed to stretch the film - it is used to measure its mechanical strength as diametric tension or tearing force. In Ph. Eur. and USP, the tensile strength test is mentioned only for surgical sutures and patches (18, 116); therefore, methods recommended for plastic industry are used as templates, e.g., DIN EN ISO 527, ASTM D $882(76,77)$. The ASTM D 882 test is one of the more widely used tests in industry to properly identify and characterize plastic films and thin sheeting materials for control and specification purposes. Both methods are used to investigate the tensile behavior of test specimens and for determining tensile strength, tensile modulus, elongation and other aspects of tensile relationships (78). According to the above tests, ODF is held between two parallel clamps and pulled. One of the innovations is the texture analyzer, used in food, cosmetics and pharmaceutical industry, due to the fact that texture significantly affects physicomechanical properties (strength, elasticity, durability, etc.) (131). The texture analyzer equipped with a load cell holds ODF between two clamps positioned at a distance of a few $\mathrm{cm}$. A strip is pulled by the top clamp until the film breaks (132). Influence of the cross-sectional area of the sample and the speed of upper clamp movement are recorded (133). To evaluate the tensile properties, a microprocessor based advanced force gauge tensiometer with a motorized test stand might also be utilized (134).

\section{Tear resistance}

The ODF material strength and ability to withstand rupture is defined as tear resistance (122). Tear resistance is the stress that corresponds to the greatest tensile force $\left(F_{\mathrm{m}}\right)$ obtained 
during the static stretch test, referring to the original cross sectional area of the sample. The film is subjected to deformation at a constant rate. Maximum force required to rupture the film is measured in Newtons (39). Measurement might be carried out according to DIN EN ISO 527 and ASTM D 882 - the sample is held between two holders and a uniform pulling force is applied until the aforementioned deformation occurs $(24,76,77,124)$.

\section{Percent elongation (\% E) and percent elongation at break}

When a sample is subjected to tensile stress, deformation of the sample occurs, resulting in sample elongation and hence stretching. Elongation measurement is primarily done to estimate the polymer plasticity. This parameter indicates the material ability to stretch without being damaged. Use of the following formula allows calculating percent elongation by measuring the increase in film length after tensile measurement:

$$
\% E=\left[L-L_{0}\right] \times 100 / L_{0}
$$

where $L$ is the final ODF length and $L_{0}$ is the initial ODF length. The point at which the film breaks after increase in its length is defined as percent elongation at break $(24,39,132)$.

\section{Young modulus}

Young modulus (elastic modulus, linear modulus) determines film stiffness. This parameter expresses the characteristic of the material relative to its linear deformation by the stress occurring in the range of elastic deformations. Test methods used for tensile strength determination can be also utilized in relation to the Young modulus (135).

Percentage elongation, tear resistance as well as Young modulus, may be evaluated by a texture analyzer, which is the most commonly used equipment for the assessment of mechanical properties. ODF is fixed in an individual sample holder. When the probe is in contact with the surface, the measurement starts. Movement of the probe proceeds at constant speed until the film is damaged (34).

\section{Folding endurance}

The folding endurance value determines film flexibility. Examining the number of folds gives an indication of ODF brittleness and is important for their storage and administration without being broken. Literature data most often indicate 300 folds per film as excellent flexibility. Measurement is taken by repeated folding at the same point at an angle of $180^{\circ}$ until the film breaks (136). Flexibility of ODF can be also determined by adapting the ASTM Bend Mandrel Test D 4338-97 (137). The film is bent over a mandrel and examined for cracks over the area of the bend under strong light. The film is assumed to be flexible if no cracks are visible at a $5 \times$ magnification (135).

\section{MOISTURE CONTENT}

Residual amounts of water or other solvents remaining in the films affect significantly their brittleness, friability, mechanical properties, stability, tackiness and adhesion. Films with high residual water can be tacky and sticky, whereas films with low water 
K. Wasilewska and K. Winnicka: How to assess orodispersible film quality? A review of applied methods and their modifications, Acta Pharm. 69 (2019) 155-176.

a)

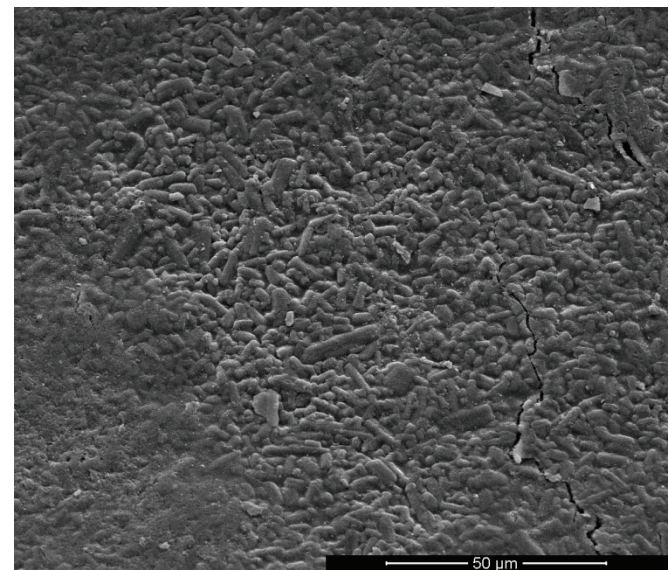

b)

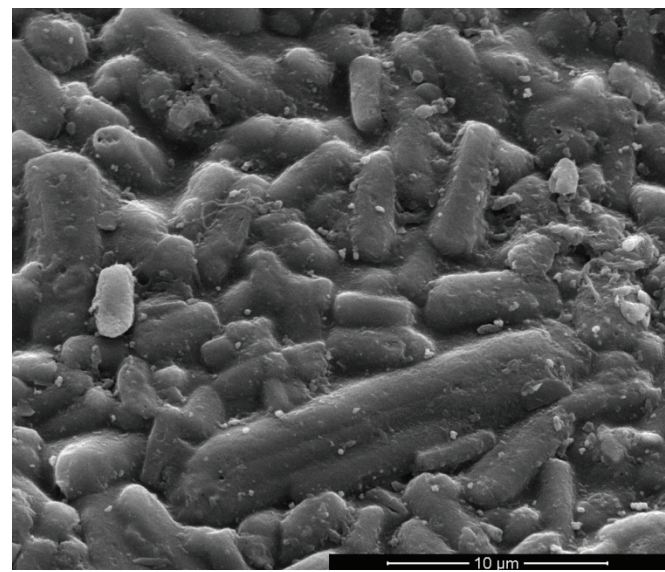

c)

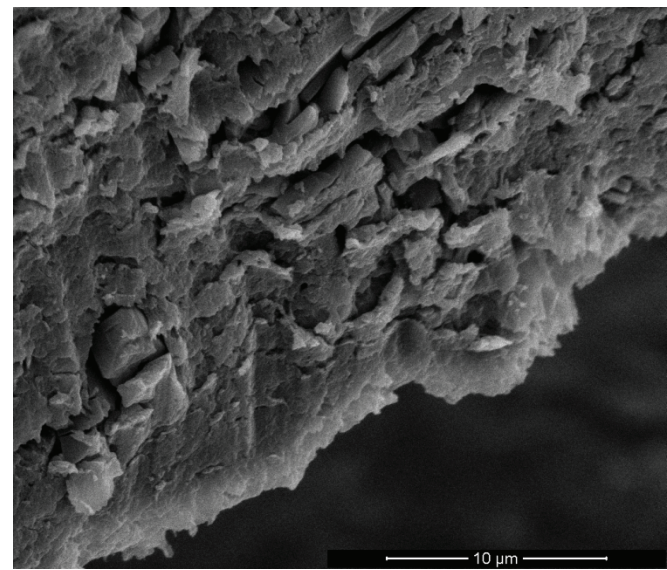

Fig. 2. Scanning electron microscope images of ODF with HPMC and loratadine under magnificatrion: a) $2000 \times$ b) and c) $10000 \times$. 
content tend to be brittle $(24,138)$. Therefore, residual water content has to be controlled and suitable packaging should be provided (8). Moisture is assessed by moisture content testing equipment, Karl Fisher titration method, dynamic vapor sorption or the most widely used weighting method. ODF is pre-weighed and heated above $100{ }^{\circ} \mathrm{C}$ until a constant mass is obtained and then re-weighed $(24,121,139,140)$.

\section{MORPHOLOGY}

An important issue is to ensure suitable API distribution and its uniformity in a film. The morphological state of ODF may alter its mechanical strength, e.g., by crystal growth. Interaction between API and polymers as well as the crystalline nature of API may result in the formation of a rough surface of films, their brittleness and loss of transparency $(138,141$, 142). API incorporated in the film might also cause recrystallization and affect mechanical or disintegration properties; it is therefore crucial to assess the texture and morphology. In order to investigate the stability of API, it is recommended to observe crystals at time zero and after storage - at possible API crystallization time (24, 133, 143, 144). Evaluation can be conducted by the following techniques: dissecting microscope, optical polarization, near-infrared spectroscopy imaging (NIR), transmission electron microscopy (TEM), X-ray diffraction or scanning electron microscopy (SEM) (Fig. 2), which appears to be the most reliable method for surface examination and evaluation of the role of composition on the crystallinity, morphology and texture of the film. These methods also provide data about ODF stability, since they reveal recrystallization of API particles in the film and possible interactions between drug and excipients. Macroscopic observation should not exhibit any bubbles, cracks or aggregates and film texture should be homogenous and smooth $(39,122,145)$.

\section{THICKNESS, MASS EXAMINATION, CONTENT UNIFORMITY}

Thickness uniformity is directly correlated with the dose contained in a single film and appropriate thickness affects comfortable administration (122). Thickness can be measured with a calibrated digital micrometer, Vernier caliper, screw gauge, microscope (with specialized software), digital camera or SEM images (146). Different number of repetitions (usually 2 to 5 at different locations, e.g., in the corners and in the middle of the film) is recommended $(14,123)$. In human volunteer studies, ODFs with a size of $2 \times 2 \mathrm{~cm}^{2}$ and 100 $\mu \mathrm{m}$ thickness as well as size $2 \times 3 \mathrm{~cm}^{2}$ and $350 \mu \mathrm{m}$ were judged as acceptable $(119,147)$.

To determine whether each film contains the same amount of drug, to be sure of the dose accuracy, weight examination is also performed. Mass variation is calculated by weighing an individual film three times and calculating the average mass for each. A deviation from average mass signifies inefficiency of the applied method and high possibility of nonuniformity in the API content $(57,139)$. To assess content uniformity in individual films, 20 films are usually examined. Drug content should be in the range from $85-115 \%$ (4).

\section{DRYNESS TEST/TACK TEST}

In order to check if ODFs are not tacky, easy to take out of the package and to keep their plane form without rolling up, the tack test is conducted. The tack is defined as film 
tenacity (related to adherence). This study aims to determine the ability of adhering to any piece of paper that is pressed into contact with the strip. The test was used primarily in the paint industry, but has also found application of evaluating ODF adherence $(27,39)$.

\section{TASTE EVALUATION}

Due to direct contact of API particles with taste buds and the necessity of product acceptability by the patient, the taste and palatability of ODFs are crucial factors (9). Under in vitro conditions, biochemical, biomimetic or ion selective detectors are utilized (148-150). There has recently been an increasing use of special panels dedicated to taste evaluation - "electronic tongues" (multisensor taste detectors with pattern recognition systems) (71, 151-153), which seem to be good alternatives to pre-testing of the formulation. Taste masking properties can be also evaluated in vitro using a dissolution test $(148,154)$. The most reliable, but ethically problematic, is the in vivo test in human volunteers. Before the examination, subjects evaluate their sensory sensibility thresholds for respective tastes, using four standard substances: tartaric acid (sour), sucrose (sweet), sodium chloride (salty), quinine (bitter). It is proposed to conduct the study in the following stages: rinsing the mouth with distilled water, placing the required amount of drug and then a film sample with the same drug content on the tongue for 30 seconds, spitting the drug and rinsing the mouth with water. For taste evaluation, the scale with the following values is usually utilized: 0 - free of bitter taste, 1 - slightly bitter, 2 - moderately bitter, 3 - very bitter (155).

\section{CONCLUSIONS}

ODFs are considered to be an attractive oral solid dosage form especially for patients struggling with swallowing difficulties and mental disabilities, as well as children and the elderly. Compared with traditional dosage forms, they seem to be a convenient and selfadministrable drug delivery platform, enhancing patient adherence and compliance. Despite monograph insertion of ODFs in the pharmacopoeias, special directions and requirements for their quality assessment have not been specified. Traditional pharmacopoeial apparatus or their modifications, as well as innovative approaches are currently utilized for their characterization. The challenge is to develop test methods that would enable carrying out unified, accurate and optimal research. Suitable and standardized methods are crucial issues to face the difficulties associated with quality evaluation; hence, this review presents conventional and modified test methods utilized to determine the characteristics of ODFs.

\section{REERENCES}

1. M. Preis, Orally disintegrating films and mini-tablets - innovative dosage forms of choice for pediatric use, AAPSPharmSciTech. 16 (2015) 234-241; https://doi.org/10.1208/s12249-015-0313-1

2. R. Alany, Oral dosage forms and drug delivery systems: tablets, oral films, liquid dosage forms, oral bioavailability enhancement, Pharm. Dev. Technol. 22 (2017) 137; https://doi.org/10.1080/108374 50.2017 .1281543

3. H. M. Batchelor and J. F. Marriott, Formulations for children: problems and solutions, Br. J. Clin. Pharmacol. 79 (2015) 405-418; https://doi.org/10.1111/bcp.12268 
4. P. Verma, A. S. Thakur, K. Deshmukh, A. K. Jha and S. Verma, Routes of drug administration, Int. J. Pharm. Studies Res. 1 (2010) 54-59.

5. P. Dey and S. Maiti, Orodispersible tablets: a new trend in drug delivery, J. Nat. Sci. Biol. 1 (2010) 2-5; https://doi.org/10.4103/0976-9668.71663

6. M. Nishimura, M. Matsuura, T. Tsukioka, H. Yamashit, N. Inagaki, T. Sugiyama and Y. Itoh, In vitro and in vivo characteristics of prochlorperazine oral disintegrating film, Int. J. Pharm. 368 (2009) 98-102; https://doi.org/10.1016/j.ijpharm.2008.10.002

7. D. A. Satyanarayana and K. P. Keshavarao, Fast disintegrating films containing anatrozole as a dosage form for dysphagia patients, Arch. Pharmacal. Res. 35 (2012) 2171-2182; https://doi.org/10.1007/ s12272-012-1215-3

8. M. Scarpa, S. Stegemann, W. K. Hsiao, H. Pichler, S. Gaisford, M. Bresciani, A. Paudel and M. Orlu, Orodispersible films: towards drug delivery in special populations, Int. J. Pharm. 523 (2017) 327335; https://doi.org/10.1016/j.ijpharm.2017.03.018

9. R. Krampe, D. Sieber, M. Pein-Hackelbusch and J. Breitkreutz, A new biorelevant dissolution method for orodispersible films, Eur. J. Pharm. Biopharm. 98 (2016) 20-25; https://doi.org/10.1016/j. ejpb.2015.10.012

10. A. F. Borges, C. Silva, J. F. Coelho and S. Simões, Oral films: Current status and future perspectives I - Galenical development and quality attributes, J. Control. Release 206 (2015) 1-19; https://doi.org/10.1016/j.jconrel.2015.03.006

11. M. Slavkova and J. Breitkreutz, Orodispersible drug formulations for children and elderly, Eur. J. Pharm. Sci. 75 (2015) 2-9; https://doi.org/10.1016/j.ejps.2015.02.015

12. J. C. Visser, H. J. Woerdenbag, L. M. Hanff and H. W.Frijlink, Personalized medicine in pediatrics: the clinical potential of orodispersible films, AAPS PharmSciTech 18 (2017) 267-272; https://doi. org/10.1208/s12249-016-0515-1

13. J. C. Visser, H. J. Woerdenbag, S.Crediet, E. Gerrits, M. A. Lesschen, W. L. J. Hinrichs, J. Breitkreutz and H. W. Frijlink, Orodispersible films in individualized pharmacotherapy: the development of a formulation for pharmacy preparations, Int. J. Pharm. 478 (2015) 155-163; https://doi.org/10.1016/j. ijpharm.2014.11.013

14. R. Bala, P. Pawar, K. Khanna and S. Arora, Orally dissolving strips: a new approach to oral drug delivery system, Int. J. Pharm. Investig. 3 (2013) 67-76; https://doi.org/10.4103/2230-973X.114897

15. A. Arya, A. Chandra, V. Sharma and K. Pathak, Fast dissolving oral films: an innovative drug delivery system and dosage form, Int. J. Chem. Tech. Res. 2 (2010) 576-583.

16. M. B. H. Mahboob, T. Riaz, M. Jamshaid, I. Bashir and S. Zulfiqar, Oral films: A comprehensive review, ICPJ 5 (2016) 111-117.

17. C. Vlachojannis, A. Al-Ahmad, E. Hellwig and S. Chrubasik, Listerine ${ }^{\circledR}$ Products: an update on the efficacy and safety, Phytother. Res. 30 (2016) 367-373; https://doi.org/10.1002/ptr.5555

18. Euroepean Pharmacopoeia 7.4, Strasbourg 2012.

19. European Medicines Agency, Guideline on the Investigation of Bioequivalence, London 2010; http:// www.ema.europa.eu/docs/en_GB/document_library/Other/2010/02/WC500073572.pdf; access date March 5, 2018.

20. FDA, CDER, Guidance for Industry - Orally Disintegrating Tablets, 2008; https://www.fda.gov/downloads/Drugs/Guidances/ucm070578.pdf; access date March 5, 2018.

21. S. D. Barnhart, Modified Release Drug Delivery Technology, Informa Healthcare, London 2008, pp. 209-216.

22. R. Sharma, R. K. Parikh, M. C. Gohel and M. M. Soniwala, Development of taste masked film of valdecoxib for oral use, Ind. J. Pharm. Sci. 2 (2007) 320-323.

23. R. Mishra and A. Amin, Formulation and characterization of rapidly dissolving films of cetirizine hydrochloride using pullulan as a film forming agent, Indian J. Pharm. Educ. Res. 45 (2015) 71-77. 
K. Wasilewska and K. Winnicka: How to assess orodispersible film quality? A review of applied methods and their modifications, Acta Pharm. 69 (2019) 155-176.

24. E. M. Hoffmann, A. Breitenbach and J. Breitkreutz, Advances in orodispersible films for drug delivery, Expert Opin. Drug Deliv. 8 (2011) 299-316; https://doi.org/10.1517/17425247.2011.553217

25. M. Preis, Oromucosal film preparations for pharmaceutical use - formulation development and analytical characterization, 2014, Düsseldorf; https://docserv.uni-duesseldorf.de/servlets/DerivateServlet/Derivate-32499/Preis_Maren_Dissertation_pdfA.pdf; access date March 5, 2018.

26. Spotscentoral care strips; http://www.comparepetstuff.com/products.php?q=SpotScent+Oral+Car e+Strips+24Pack; access date March 5, 2018.

27. R. P. Dixit and S. P. Puthil, Oral strip technology: overview and future potential, J. Control. Release 139 (2009) 94-107; https://doi.org/10.1016/j.jconrel.2009.06.014

28. J. Krause and J. Breitkreutz, Improving drug delivery in pediatric medicine, Pharm. Med. 22 (2008) 41-50; https://doi.org/10.1007/BF03256681

29. V. Reiner, N. Giarratana, N. C. Monti, A. Breitenbach and P. Klaffenbach, Rapidfilm: an innovative pharmaceutical form designed to improve patient compliance, Int. J. Pharm. 393 (2010) 55-60; https://doi.org/10.1016/j.ijpharm.2010.03.055

30. Sildenafil Sandoz orodispersible film public assessment report, 2013; http://www.mhra.gov.uk/ home/groups/par/documents/websiteresources/con303958.pdf; access date March 5, 2018.

31. Ivy film patent information leaflet, 2014; http://lamar.co.za/sites/default/files/files/IvyFilm \%20PIL \%20L10024_14A_PROOF.pdf; access date March 5, 2018.

32. Clobazam OSF data; http://www.pharmajournalist.com/pharma-news/fda-accepts-aquestive-therapeutics-nda-clobazam-osf-treating-lgs-patients/; access date March 5, 2018.

33. S. V. Kumar, B. Gavaskar, G. Sharan and Y. Madhusudan Rao, Overview on fast dissolving films, Int. J. Pharm. Pharm. Sci. 2 (2010) 29-33.

34. S. Karki, K. Hyeongmin, H. Kim, S. J. Na, D. Shin, K. Jo and J. Lee, Thin films as an emerging platform for drug delivery, AJPS. 11 (2016) 559-574; https://doi.org/10.1016/j.ajps.2016.05.004

35. M. Preis, J. Breitkreutz and N. Sandler, Perspective: Concepts of printing technologies for oral film formulations, Int. J. Pharm. 494 (2015) 578-584; https://doi.org/10.1016/j.ijpharm.2015.02.032

36. SildenafiIBSAorodispersible film: https://www.drugs.com/uk/sildenafil-ibsa-100-mg-orodispersible-film-leaflet.html; access date March 5, 2018.

37. L. Loprete, C. Leuratii, V. Frangione and M. Radicioni, Pharmacokinetics of a novel sildenafil orodispersible film administered by the supralingual and the sublingual route to healthy men, Clin. Drug Investig. 38 (2018) 765-772; https://doi.org/10.1007/s40261-018-0665-x

38. M. D. Siddiqui, G. Garg and P. Sharma, A short review on a novel approach in oral fast dissolving drug delivery system and their patents, Adv. Biol. Res. 5 (2011) 291-303.

39. B. Bhyan, H. Jangra, M. Kaurand are H. Singh, Orally fast dissolving films: innovations in formulation and technology, Int. J. Pharm. Sci. Rev. Res. 9 (2011) 50-56.

40. E. Chidi, N. Nwobodo and O. Raymond, Development and evaluation of fast dissolving thin films of aripiprazole, UJPR. 2 (2017) 23-27; https://doi.org/10.22270/ujpr.v2i5.R5

41. M. Hariharan and A. Bogue, Orally dissolving film strips (ODFS): the final evolution of orally dissolving dosage forms, Drug Deliv. Technol. 9 (2009) 24-29.

42. A. Alayoubi, L. Hayens, B. Daihom, R. Helms and H. Almoazen, Development of a fast dissolving film of epinephrine hydrochloride as a potential anaphylactic treatment for pediatrics, Pharm. Dev. Technol. 22 (2017) 1012-1016; https://doi.org/10.3109/10837450.2015.1131715

43. J. Aggarwal, G. Singh, S. Saini and A. C. Rana, Fast dissolving films: a novel approach to oral drug delivery, IRJP 2 (2011) 69-74.

44. Y. Thabet and J. Breitkreutz, Orodispersible films: product transfer from lab-scale to continuous manufacturing, Int. J. Pharm. 535 (2018) 285-292; https://doi.org/10.1016/j.ijpharm.2017.11.021

45. K. B. Liew, Y. T. Tan and K. K. Peh, Effect of polymer, plasticizer and filler on orally disintegrating film, Drug. Dev. Ind. Pharm. 40 (2014) 110-119; https://doi.org/ 10.3109/03639045.2012.749889 
K. Wasilewska and K. Winnicka: How to assess orodispersible film quality? A review of applied methods and their modifications, Acta Pharm. 69 (2019) 155-176.

46. V. F. Patel, F. Liu and M. B. Brown, Advances in oral transmucosal drug delivery, J. Control. Release 153 (2011) 106-116; https://doi.org/10.1016/j.jconrel.2011.01.027

47. A. V. Yadav, A. S. Shete, A. P. Dabke, P. V. Kulkarni and S. S. Sakhare, Co-crystals: a novel approach to modify physicochemical properties of active pharmaceutical ingredients, Indian J. Pharm. Sci. 71 (2009) 359-370; https://doi.org/10.4103/0250-474X.57283

48. M. R. Gigliobianco, C. Casadidio, R. Censi and P. Di Martino, Nanocrystals of poorly soluble drugs: drug bioavailability and physicochemical stability, Pharmaceutics 10 (2018) E134.;https://doi. org/10.3390/pharmaceutics10030134

49. S. Rao, Y. Song, F. Peddie and A. M. Evans, Particle size reduction to the nanometer range: a promising approach to improve buccal absorption of poorly water-soluble drugs, Int. J. Nanomedicine 6 (2011) 1245-1251; hhtps://doi.org/10.2147/IJN.S19151

50. Z. Gao, S. Rohani, J. Gong and J. Wang, Recent developments in the crystallization process: toward the pharmaceutical industry, Engineering 3 (2017) 343-353; https://doi.org/10.1016/J.ENG.2017.03.022

51. P. R. Vuddanda, M. Montenegro-Nicolini J. O. Morales and S. Velaga, Effect of surfactants and drug load on physico-mechanical and dissolution properties of nanocrystalline tadalafil-loaded oral films, Eur. J. Pharm. Biopharm. 85 (2013) 1348-1356; https://doi.org./10.1016/j.ejps.2017.08.019

52. B. D. Kevadiya, M. Barvaliya, L. Zhang, A. Anovadiya, H. Brahmbhatt, P. Paul and C. Tripathi, Fenofibrate nanocrystals embedded in oral strip-films for bioavailability enhancement, Bioengineering (Basel). 13 (2018) E16; https://doi.org/10.3390/bioengineering5010016

53. D. Steiner, J. H. Finke and A. Kwade, Efficient production of nanoparticle-loaded orodispersible films by process integration in a stirred media mill, Int. J. Pharm. 511 (2016) 804-813; https://doi. org/10.1016/j.ijpharm.2016.07.058

54. V. Garsuch and J. Breitkreutz, Comparative investigations on different polymers for the preparation of fast-dissolving oral films, J. Pharm. Pharmacol. 62 (2010) 539-545; https://doi.org/10.1211/ jpp.62.04.0018

55. M. Irfan, S. Rabel, Q. Bukhtar, M. I. Quadir, F. Jabeen and A. Khan, Orally disintegrating films: a modern expansion in drug delivery systems, Saudi Pharm. J. 24 (2016) 537-546; https://doi.org/10.1016/j.jsps.2015.02.024

56. M. J. Chen, G. Tirol, C. Bass, C. M. Corniello, G. Watson and I. Sanchezet, Castable edible pharmaceutical films, Drug. Delivery Technol. 8 (2008) 34-41.

57. F. Cilurzo, I. E. Cupone, P. Minghetti, F. Selmin and L. Montanari, Fast dissolving films made of maltodextrins, Eur. J. Pharm. Biopharm. 70 (2008) 895-900; https://doi.org/: 10.1016/j.ejpb.2008.06.032

58. F. Cilurzo, I. E. Cupone, P. Minghetti, S. Buratti, F. Selmin, C. G. M. Gennari and L. Montanari, Nicotine fast dissolving films made of maltodextrins: a feasibility study, AAPS PharmSciTech 11 (2010) 1511-1517; https://doi.org/10.1208/s12249-010-9525-6

59. J. S. Boateng, K. H. Matthews, A. D. Auffret, M. J. Humphrey, H. N. Stevens and G. M. Eccleston, In vitro drug release studies of polymeric freeze-dried wafers and solvent-cast films using paracetamol as a model soluble drug, Int. J. Pharm. 378 (2009) 66-72; https://doi.org/10.1016/j.ijpharm.2009.05.038

60. J. S. Boateng, H. N. Stevens, G. M. Eccleston, A. D. Auffret, M. J. Humphrey and K. H. Matthews, Development and mechanical characterization of solvent-cast polymeric films as potential drug delivery systems to mucosal surfaces, Drug Dev. Ind. Pharm. 35 (2009) 986-996; https://doi. org/10.1080/03639040902744704

61. Y. S. Pathare, V. S. Hastak and A. N. Bajaj, Polymers used for fast disintegrating oral films: a review, Int. J. Pharm. Sci. Rev. Res. 21 (2013) 169-178.

62. P. R. Vuddanda, M. Montenegro-Nicolini, J. O. Morales and S. Velaga, Effect of plasticizers on the physico-mechanical properties of pullulan based pharmaceutical oral films, Eur. J. Pharm. Sci. 96 (2017) 290-298; https://doi.org/10.1016/j.ejps.2016.09.011 
K. Wasilewska and K. Winnicka: How to assess orodispersible film quality? A review of applied methods and their modifications, Acta Pharm. 69 (2019) 155-176.

63. C. Giovino, I. Ayensu, J. Tetteh and J. S. Boateng, An integrated buccal delivery system combining chitosan films impregnated with peptide loaded PEG-b-PLA nanoparticles, Colloids Surf. B. Biointerfaces 112 (2013) 9-15; https://doi.org/10.1016/j.colsurfb.2013.07.019

64. Y. Murata, T. Isobe, K. Kofuji, N. Nishida and R. Kamaguchi, Preparation of fast dissolving films for oral dosage from natural polysaccharides, Materials 3 (2010) 4291-4299; https://doi.org/10.3390/ ma3084291

65. P. Nagar, I. Chauhan and M. Yasir, Insights into polymers: film formers in mouth dissolving films, Drug Invent. Today 3 (2011) 280-289.

66. I. Ito, A. Ito and S. Unezaki, Preparation of an oral acetaminophen film that is expected to improve medication administration: effect of polyvinylpyrrolidone on physical properties of the film, Drug Discov. Ther. 10 (2016) 156-162; https://doi.org/10.5582/ddt.2016.01034

67. D. Jain, E. Carvalho and R. Banerjee, Biodegradable hybrid polymeric membranes for ocular drug delivery, Acta Biomater. 6 (2010) 1370-1379; https://doi.org/10.1016/j.actbio.2009.11.001

68. A. S. Kulkarni, H. A. Doekule, M. S. Mane and D. M. Ghadge, Exploration of different polymers for using the formulation of oral fast dissolving strips, J. Curr. Pharm. Res. 1 (2010) 33-35.

69. S. Ali and A. Quadir, High molecular weight povidone polymer-based films for fast-dissolving drug delivery application, Drug Delivery Technology 7 (2007) 36-43.

70. Y. Sakuda, A. Ito, M. Sasatsu and Y. Machida, Preparation and evaluation of medicinal carbon oral films, Chem. Pharm. Bull. 58 (2010) 454-457.

71. N. Cao, X. Yang and Y. Fu, Effects of various plasticizers on mechanical and water vapor barrier properties of gelatin films, Food Hydrocolloids 23 (2009) 729-735; https://doi.org/10.1016/j.foodhyd.2008.07.017

72. A. Amelian, E. Szymańska and K. Winnicka, Formulation and characterization of loratadine containing orodispersible lyophilizates and films, Acta Pol. Pharm.-Drug Research 74 (2017) 1533-1541.

73. M. Preis, M. Pein and J. Breitkreutz, Development of a taste-masked orodispersible film containing dimenhydrinate, Pharmaceutics 4 (2012) 551-562; https://doi.org/ 10.3390/pharmaceutics4040551

74. P. L. Travers, Mary Poppins, New York, Howe, 1934.

75. C. K. Brown, H. D. Friedel, A. R. Barker, L. F. Buhse, S. Keitel, T. L. Cecil, J. Kraemer, J. M. Morris, C. Reppas, M. P. Stickelmeyer, C. Yomota and P. V. Shah, FIP/AAPS joint workshop report: dissolution/in vitro release testing of novel/special dosage forms, AAPS PharmSciTec 12 (2011) 782-794; https://doi.org/10.1208/s12249-011-9634-x

76. Plastics - determination of tensile properties, DIN EN ISO 527-3, 2012; https://www.iso.org/standard/56045.html; access date March 5, 2018.

77. Standard test method for tensile properties of thin plastic sheeting, ASTM D 882-02, 2012; https:// www.astm.org/Standards/D882; access date March 5, 2018.

78. M. Preis, K. Knop and J. Breitkreutz, Mechanical strength test for orodispersible and buccal films, Int. J. Pharm. 461 (2014) 22-29; https://doi.org/10.1016/j.ijpharm.2013.11.033

79. S. Klein, The use of biorelevant dissolution media to forecast the in vivo performance of a drug, AAPS J 12 (2010) 397-406; https://doi.org/10.1208/s12248-010-9203-3

80. T. Nagaraju, T. Gowthami, M. Rajashekar, S. Sandeep, M. Mallesham, D. Sathish and Y. S. Kumar, Comprehensive review on oral disintegrating films, Curr. Drug Deliv. 10 (2013) 96-108.

81. D. Markl and I. A. Zeitler, A review of disintegration mechanisms and measurement techniques, Pharm. Res. 34 (2017) 890-917; https://doi.org/10.1007/s11095-017-2129-z

82. M. Siewert, J. Dressman, C. Brown and V. P. Shah, FIP/AAPS guidelines for dissolution/in vitro release testing of novel/special dosage forms, AAPS PharmSciTech. 4 (2003) 43-52; https://doi. org/10.1208/pt040107

83. European Pharmacopoeia 8, Strasbourg 2014 
K. Wasilewska and K. Winnicka: How to assess orodispersible film quality? A review of applied methods and their modifications, Acta Pharm. 69 (2019) 155-176.

84. United States Pharmacopoeia 37, National Formulary 32, US Pharmacopeial Convention, Rockville 2014.

85. J. Al-Gousous and P. Langguth, Oral solid dosage form disintegration testing - the forgotten test, J. Pharm. Sci. 104 (2015) 2664-2675; https://doi.org/10.1002/jps.24303

86. S. Gittings, N. Turnbull, C. J. Roberts and P. Gershkovich, Dissolution methodology for taste masked oral dosage forms, J. Control. Release 173 (2014) 32-42; https://doi.org/10.1016/j.jconrel.2013.10.030

87. H. K. Batchelor, N. Fotaki and S. Klein, Paediatric oral biopharmaceutics: key considerations and current challenges, Adv. Drug Deliv. Rev. 73 (2014) 102-126; https://doi.org/10.1016/j.addr.2013.10.006

88. J. C. Visser, W. M. Dohmen, W. L. Hinrichs, J. Breitkreutz, H. W. Frijlinkand and H. J. Woerdenbag, Quality by design approach for optimizing the formulation and physical properties of extemporaneously prepared orodispersible films, Int. J. Pharm. 485 (2015) 70-76; https://doi.org/10.1016/j.ijpharm.2015.03.005

89. H. Okamoto, H. Taguchi, K. Iida and K. Danjo, Development of polymer film dosage forms of lidocaine for buccal administration, I. Penetration rate and release rate, J. Control. Release 77 (2001) 253-260.

90. K. Müller, C. Fingueroa, C. Martinez, M. Madel, E. Obreque, A. Peña-Neira, I. Morales-Bozo, H. Toledo and R. O. Lopez-Solis, Measurement of saliva volume in the mouth of members of a trained sensory panel using a beetroot (Beta vulgaris) extract, Food Quality and Preference 21 (2010) 569-574; https://doi.org/10.1016/j.foodqual.2010.03.005

91. M. Gohel, M. Patel, A. Amin, R. Agrawal, R. H. Dave and N. Bariya, Formulation design and optimization of mouth dissolve tablets of nimesulide using vacuum drying technique, AAPS PharmSciTech. 5 (2004) e36; https://doi.org/10.1208/pt050336

92. P. C. Patil, S. K. Shirvastava, S. Vaidehi and P. Ashwini, Oral fast dissolving drug delivery system: a modern approach for patient compliance, Int. J. Drug Regulat. Affairs 2 (2014) 49-60.

93. D. A. El-Setouhy and N. S. A. El-Malak, Formulation of novel tianeptine sodium orodispersible film, AAPS PharmSciTech 11 (2010) 1018-1025; https://doi.org/10.1208/s12249-010-9464-2

94. I. Speer, D. Steiner, Y. Thabet, J. Breitkreutz and A. Kwade, Comparative study on disintegration methods for oral film preparations, Eur. J. Pharm. Biopharm. 132 (2018) 50-61; https://doi.org/10.1016/j. ejpb.2018.09.005

95. M. Preis, D. Gronkowsky, D. Grytzan and J. Breitkreutz, Comparative study on novel test systems to determine disintegration time of orodispersible films, J. Pharm. Pharmacol. 66 (2014) 1102-1111; https://doi.org/10.1111/jphp.12246

96. A. Low, S. L. Kok, Y. M. Khong, S. Y. Chan and R. Gokhale, A new test unit for disintegration endpoint determination of orodispersible films, J. Pharm. Sci. 104 (2015) 3893-3903; https://doi. org/10.1002/jps.24609

97. G. Szakonyi and R. Zelkó, Prediction of oral disintegration time of fast disintegrating tablets using texture analyzer and computational optimization, Int. J. Pharm. 448 (2013) 346-353; https://doi.org/10.1016/j.ijpharm.2013.03.047

98. R. H. Dave, D. A. Shah and P. G. Patel, Development and evaluation of high loading oral dissolving film of aspirin and acetaminophen, J. Pharm. Sci. Pharmacol. 1 (2014) 112-122; https://doi.org/10.1166/ jpsp.2014.1014

99. PharmaTest ${ }^{\circledR}$ film disintegration tester PTZ AUTO EZ: https:/www.pharma-test.de/en/products/ galenic-instruments/tablet-disintegration-testing/p-pt-odf/; access date October 20, 2018.

100. J. I. Kim, S. M. Cho, J. H. Cui, Q. R. Cao, E. Oh and B. J. Lee, In vitro and in vivo correlation of disintegration and bitter taste masking using orally disintegrating tablet containing ion exchange resin-drug complex, Int. J. Pharm. 455 (2013) 31-39; https://doi.org/10.1016/j.ijpharm.2013.07.072 
K. Wasilewska and K. Winnicka: How to assess orodispersible film quality? A review of applied methods and their modifications, Acta Pharm. 69 (2019) 155-176.

101. S. Gittings, N. Turnbull, B. Henry, C. J. Roberts and P. Gershkovich, Characterisation of human saliva as a platform for oral dissolution medium development, Eur. J. Pharm. Biopharm. 91 (2015) 16-24; https://doi.org/.1016/j.ejpb.2015.01.007

102. M. Tiwari, Science behind human saliva, J. Nat. Sci. Biol. Med. 2 (2011) 53-58.

103. G. R. Batista, C. Rocha Gomes Torres, B. Sener, T. Attin and A. Wiegand, Artificial saliva formulations versus human saliva pretreatment in dental erosion experiments, Caries Res. 50 (2016) 78-86; https://doi.org/10.4103/0976-9668.82322

104. R. G. Schipper, E. Silletti and M. H. Vingerhoeds, Saliva as research material: biochemical, physicochemical and practical aspects, Arch. Oral Biol. 52 (2007) 1114-1135; https://doi.org/10.1016/j.archoralbio.2007.06.009

105. S. P. Humphrey and R. T. Williamson, A review of saliva: normal composition, flow and function, J. Prosthet. Dent. 85 (2001) 162-169; https://doi.org/ 10.1067/mpr.2001.113778

106. S. Saini, A. Nanda, M. Hooda and K. Chaudhary, Fast dissolving films (FDF): innovative drug delivery system, Pharmacologyonline 2 (2011) 919-928.

107.M. R. C. Marques, R. Loebenberg and M. Almukainzi, Simulated biological fluids with possible application in dissolution testing, Dissolut. Technol. 18 (2011) 15-28; https://doi.org/ 10.14227/ DT180311P15.

108. S. Gittings, Development of biorelevant simulated salivary fluids for application in dissolution testing, PhD thesis, University of Nottingham; http://eprints.nottingham.ac.uk/39862/1/Thesis \%20FINAL \%20version \%20for \%20submission_Sally \%20Gittings.pdf; access date March 5, 2018.

109. M. Guhmann, M. Preis, F. Gerber, N. Pollinger and J. Breitkreutz, W. Weitschies, Development of oral taste masked diclofenac formulations using a taste sensing system, Int. J. Pharm. 438 (2012) 81-90; https://doi.org/10.1016/j.ijpharm.2012.08.047

110. A. S. S. Amal, S. Hussain and M. A. Jalaluddin, Preparation of artificial saliva formulation, 2015; https://www.researchgate.net/publication/316472372; access date March 5, 2018

111. G. M. Queiroz, L. F. Silva, J. T. Ferreira, J. A. Gomes and L. Sathler, Electrochemical behavior and pH stability of artificial salivas for corrosion tests, Braz. Oral Res. 21 (2007) 209-215.

112. Q. Wang, N. Fotaki and Y. Mao, Biorelevant dissolution: methodology and application in drug development, Dissolution Technologies 16 (2018) 6-12; https://doi.org/10.14227/DT160309P6

113. Artificial salivas by Pickering laboratories; http://www.pickeringtestsolutions.com/artificial-saliva2/; access data March 5, 2018.

114. M. Dilea, A. Mazare, D. Ionita and I. Demetrescu, Comparison between corrosion behaviour of implant alloys Ti6Al7Nb and Ti6Al4Zr in artificial saliva, Materials and Corrosion 64 (2013) 493499; https://doi.org/10.1002/maco.201206526

115. European Pharmacopoeia 5 with Supplements 5.1 and 5.2, Strasbourg 2005.

116. United States Pharmacopeia 29, National Formulary 24, US Pharmacopeial Convention, Rockville 2006.

117. W. Brniak, R. Jachowicz and P. Pełka, The practical approach to the evaluation of methods used to determine the disintegration time of orally disintegrating tablets (ODTs), Saudi Pharm. J. 23 (2015) 437-443; https://doi.org/10.1016/j.jsps.2015.01.015

118. B. Shen, C. Shen, X. D. Yuan, J. X. Bai, Q. Y. Lv, H. Xu, L. Dai, C. Yu, J. Han and H. L. Yua, Development and characterization of an orodispersible film containing drug nanoparticles, Eur. J. Pharm. Biopharm. 85 (2013) 1348-1356; https://doi.org/10.1016/j.ejpb.2013.09.019

119. H. Shimoda, K. Taniguchi, M. Nishimura, K. Matsuura, T. Tsukioka, H. Yamashita, N. Inagaki, K. Hirano, M. Yamamoto, Y. Kinosada and Y. Itoh, Preparation of a fast dissolving oral thin film containing dexamethasone: a possible application to antiemesis during cancer chemotherapy, Eur. J. Pharm. Biopharm. 73 (2009) 361-365; https://doi.org/10.1016/j.ejpb.2009.08.010 
K. Wasilewska and K. Winnicka: How to assess orodispersible film quality? A review of applied methods and their modifications, Acta Pharm. 69 (2019) 155-176.

120. J. Shen and D. J. Burgess, In vitro dissolution testing strategies for nanoparticulate drug delivery systems: recent developments and challenges, Drug Deliv. Transl. Res. 3 (2013) 409-415; https://doi. org/10.1007/s13346-013-0129-z

121. R. C. Mashru, V. B. Sutariya, M. G. Sankalia and P. P. Parikh, Development and evaluation of fastdissolving film of salbutamol sulphate, Drug Dev. Ind. Pharm. 31 (2005) 25-34; https://doi. org/10.1081/DDC-43947.

122. A. B. Nair, R. Kumria, S. Harsha, M. Attimarad, B. E. Al-Dhubiab and I. A. Alhaider, In vitro techniques to evaluate buccal films, J. Control. Release 166 (2013) 10-21; https://doi.org/10.1016/j. jconrel.2012.11.019

123. R. Kumria, V. Gupta, S. Bansal, J. Wadhwa and A. B. Nair, Oral buccoadhesive films of ondansetron: development and evaluation, Int. J. Pharm. Investig. 3 (2013) 112-118; https://doi.org/10.4103/ 2230-973X.114894

124. W. Brniak, E. Maślak and R. Jachowicz, Orodispersible films and tablets with prednisolone microparticles, Eur. J. Pharm. Sci. 75 (2015) 81-90; https://doi.org/10.1016/j.ejps.2015.04.006

125. A. Adrover, A. Pedacchia, S. Petralito and R. Spera, In vitro dissolution testing of oral thin films: A comparison between USP 1, USP 2 apparatuses and a new millifluidic flow-through device, ChERD. 95 (2015) 173-178; https://doi.org/ 10.1016/j.cherd.2014.10.020

126. Y. Xia, F. Chen, H. Zhang and C. Luo, A new method for evaluating the dissolution oforodispersible films, Pharm. Dev. Technol. 20 (2015) 375-379; https://doi.org/10.3109/10837450.2014.882936

127. L. Perioli, V. Ambrogi, F. Angelici, M. Ricci, S. Giovagnoli, M. Capuccella and C. Rossi, Development of mucoadhesive patches for buccal administration of ibuprofen, J. Control. Release 99 (2005) 73-82; https://doi.org/10.1016/j.jconrel.2004.06.005

128. M. A. Repka, K. Gutta, S. Prodduturi, M. Munjal and S. P. Stodghill, Characterization of cellulosic hot-melt extruded films containing lidocaine, Eur. J. Pharm. Biopharm. 59 (2005) 189-196; https://doi.org/10.1016/j.ejpb.2004.06.008

129. J. O. Morales and J. T. McConville, Manufacture and characterization of mucoadhesive buccal films, Eur. J. Pharm. Biopharm. 77 (2011) 187-199; https://doi.org/10.1016/j.ejpb.2010.11.023

130. K. K. Peh and C. F. Wong, Polymeric films as vehicle for buccal delivery: swelling, mechanical, and bioadhesive properties, J. Pharm. Pharm. Sci. 2 (1999) 53-61.

131. A. Tai, R. Bianchini and R. Jachowicz, Texture analysis of cosmetic/pharmaceutical raw materials and formulation, Int. J. Cosmet. Sci. 36 (2014) 291-304; https://doi.org/10.1111/ics.12125

132. T. S. Naik, A. Khsle and H. Kanekar, Evaluation of mouth dissolving films: physical and chemical method, Int. J. Pharm. Phytopharmacol. Res. 4 (2014) 62-65.

133. H. Landová and D. Vetchý, Evaluation of the influence of formulation and process variables on mechanical properties of oral mucoadhesive films using multivariate data analysis, Biomed Res. Int. 7 (2014) 9; https://doi.org/10.1155/2014/179568

134. M. S. Ali and C. D. Vijendar, Formulation and evaluation of fast dissolving oral films of diazepam, J. Pharmacovigilance 4 (2016) 210; https://doi.org/10.4172/2329-6887.1000210

135. V. Y. Londhe and K. B. Umalkar, Formulation development and evaluation of fast dissolving film of telmisartan, Ind. J. Pharm. Sci. 74 (2012) 122-126; https://doi.org/10.4103/0250-474X.10384

136. D. Mukherjee and S. Bharath, Design and characterization of double layered mucoadhesive system containing bisphosphonate derivative, ISRN Pharm. 19 (2013) 604-690; https://doi.org/10.1155/2013/ 604690

137. Standard test method for flexibility determination of supported adhesive films by mandrel bend, ASTM D 4338-97, 2016; https://www.astm.org/Standards/D4338.htm; access data March 5, 2018.

138. S. Gaisford, A. Verma, M. Saunders and P. G. Rovall, Monitoring crystallisation of drugs from fast-dissolving oral films with isothermal calorimetry, Int J. Pharm. 380 (2009) 105-111; https://doi. org/10.1016/j.ijpharm.2009.07.006 
K. Wasilewska and K. Winnicka: How to assess orodispersible film quality? A review of applied methods and their modifications, Acta Pharm. 69 (2019) 155-176.

139. A. P. Gorle and S. G. Gattani, Development and evaluation of ocular drug delivery system, Pharm. Dev. Technol. 15 (2010) 46-52; https://doi.org/10.3109/10837450902967947

140. K. B. Liew, Y. T. Tan and K. K. Peh, Characterization of oral disintegrating film containing donepezil for Alzheimer disease, AAPS PharmSciTech 13 (2012) 134-142; https://doi.org/10.1208/s12249011-9729-4

141. F. Kianfar, B. Z. Chowdhry, M. D. Antonijevic and J. S. Boateng, Novel films for drug delivery via the buccal mucosa using model soluble and insoluble drugs, Drug Dev. Ind. Pharm. 38 (2012) 1207 - 1220; https://doi.org/ 10.3109/03639045.2011.644294

142. V. Garsuch and J. Breitkreutz, Novel analytical methods for the characterization of oral wafers, Eur. J. Pharm. Biopharm. 73 (2009) 195-201; https://doi.org/10.1016/j.ejpb.2009.05.010

143. R. Bahri-Najafi, N. Tavakoli, M. Senemar and M. Peikanpour, Preparation and pharmaceutical evaluation of glibenclamide slow release mucoadhesive buccal film, Res. Pharm. Sci. 9 (2014) 213223.

144. R. Patel, S. Naik, J. Patel and A. Baria, Formulation development and evaluation of mouth melting film of ondansetron, Arch. Pharm. Sci. Res. 1 (2009) 212-217.

145. K. Hermans, D. Van den Plas, S. Kerimova, R. Carleer, P. Adriaensens, W. Weyenberg and A. Ludwig, Development and characterization of mucoadhesive chitosan films for ophthalmic delivery of cyclosporine, Int. J. Pharm. 472 (2014) 10-19; https://doi.org/10.1016/j.ijpharm.2014.06.017

146. G. L. Prabhushankar, B. Gopalkrishna, K. M. Manjunatha and C. H. Girisha, Formulation and evaluation of levofloxacin dental films for periodontitis, Int. J. Pharm. Pharm. Sci. 2 (2010) 162-168.

147. R. Krampe, C. Visser, H. W. Frijlink, J. Breitkreutz, H. J. Woerdenbag and M. Preis, Oromucosal film preparations: points to consider for patient centricity and manufacturing processes, Expert Opin. Drug Deliv. 13 (2016) 493-506.

148. J. A. Mennella and A. C. Spector, The bad taste of medicines: overview of basic research on bitter taste, Clin. Ther. 35 (2013) 1225-1246; https://doi.org/10.1016/j.clinthera.2013.06.007

149. L. Lu, X. Hu and Z. Zhu, Biomimetic sensors and biosensors for qualitative and quantitative analyses of five basic tastes, TrAC. 83 (2017) 58-70; https://doi.org/10.1016/j.trac.2016.12.007

150. N. Funasaki, I. Uratsuji, T. Okuno, S. Hirota and S. Neya, Masking mechanisms of bitter taste of drugs studied with ion selective electrodes, Chem. Pharm. Bull. 54 (2006) 1155-1161.

151. A. Amelian, M. Szekalska, P. Ciosek, A. Basa and K. Winnicka, Characterization and taste masking evaluation of microparticles with cetirizine dihydrochloride and methacrylate-based copolymer obtained by spray drying, Acta Pharm. 67 (2017) 113-124; https://doi.org/10.1515/acph-20170002

152. F. Cilurzo, I. E. Cupone, P. Minghetti, S. Buratti, C. G. Gennari and L. Montanari, Diclofenac fastdissolving film: suppression of bitterness by a taste-sensing system, Drug Dev. Ind. Pharm. 37 (2011) 252-259; https://doi.org/10.3109/03639045.2010.505928

153. K. Woertz, C. Tissen, P. Kleinebudde and J. Breitkreutz, Taste sensing systems (electronic tongues) for pharmaceutical applications, Int. J. Pharm. 417 (2011) 256-271; https://doi.org/10.1016/j.ijpharm.2010.11.028

154. S. Gittings, N. Turnbull, C. J. Roberts and P. Gershkovich, Dissolution methodology for taste masked oral dosage forms, J. Control. Release 173 (2014) 32-42; https://doi.org/10.1016/j.jconrel.2013.10.030

155. A. Amelian, K. Wasilewska, M. Wesoły, P. Ciosek-Skibińska and K. Winnicka, Taste-masking assessment of orally disintegrating tablets and lyophilisates with cetirizine dihydrochloridemicroparticles, Saudi Pharm. J. 25 (2017) 1144-1150; https://doi.org/10.1016/j.jsps.2017.06.001 